\title{
"Muslims are not Terrorists": Islamic State Coverage, Journalistic Differentiation Between Terrorism and Islam, Fear Reactions, and Attitudes Toward Muslims
}

\author{
Christian von Sikorski, Desirée Schmuck, Jörg Matthes \& Alice Binder
}

To cite this article: Christian von Sikorski, Desirée Schmuck, Jörg Matthes \& Alice Binder (2017) "Muslims are not Terrorists": Islamic State Coverage, Journalistic Differentiation Between Terrorism and Islam, Fear Reactions, and Attitudes Toward Muslims, Mass Communication and Society, 20:6, 825-848, DOI: 10.1080/15205436.2017.1342131

To link to this article: https://doi.org/10.1080/15205436.2017.1342131

Copyright @ Christian von Sikorski, Desirée Published with license by Taylor \& Francis.

Submit your article to this journal

View related articles
Accepted author version posted online: 15 Jun 2017. Published online: 04 Aug 2017.

山 Article views: 2565

Citing articles: 1 View citing articles 


\title{
"Muslims are not Terrorists": Islamic State Coverage, Journalistic Differentiation Between Terrorism and Islam, Fear Reactions, and Attitudes Toward Muslims
}

\author{
Christian von Sikorski, Desirée Schmuck, Jörg Matthes, and \\ Alice Binder \\ Department of Communication \\ University of Vienna
}

Previous research shows that news about Islamist terrorism can seriously affect citizens' fear reactions and influence non-Muslims' out-group perceptions of Muslims. We argue that news coverage that explicitly links Islam to terrorism or terrorists of the Islamic State (IS) may trigger fears in non-Muslim individuals. In contrast, news differentiation (i.e., explicitly distinguishing between Muslims and Muslim terrorists) may dampen particular

Christian von Sikorski (Ph.D., German Sport University Cologne, 2014), is a postdoctoral researcher in the Department of Communication at the University of Vienna as well as a visiting professor of media psychology in the Institute for Communication Psychology and Media Education at the University of Koblenz-Landau. His research interests include media effects, research methods, and online and visual communication with a special interest in terrorism news coverage and political scandals.

Desirée Schmuck (Ph.D., University of Vienna, 2017), is a postdoctoral researcher in the Department of Communication at the University of Vienna. Her research interests include the effects of political communication with a special interest in right-wing populism and terrorism news coverage.

Jörg Matthes (Ph.D., University of Zurich, 2007) is a professor of communication science in and the director of the Department of Communication at the University of Vienna. His research interests include advertising effects, the process of public opinion formation, news framing, and empirical methods.

Alice Binder (M.A., University of Vienna, 2016) is a doctoral candidate in the Department of Communication at the University of Vienna. Her research interests include political participation and children and media.

Correspondence should be addressed to Jörg Matthes, Department of Communication, University of Vienna, Währingerstr. 29, Vienna 1090, Austria. E-mail: joerg.matthes@univie.ac.at

This is an Open Access article distributed under the terms of the Creative Commons Attribution License (http://creativecommons.org/licenses/by/4.0/), which permits unrestricted use, distribution, and reproduction in any medium, provided the original work is properly cited. 
fear reactions in citizens. To test the specific effects of news differentiation, a controlled laboratory experiment was conducted. Results showed that undifferentiated news about IS terrorism increased participants' fear of terrorism and resulted in hostile perceptions toward Muslims in general. However, fear of terrorism only enhanced hostile attitudes toward Muslims for individuals with negative and moderately positive prior experiences with Muslims. For those with very positive experiences, no such relationship was found. Implications of these findings for journalism practice and intergroup relations in multicultural societies are discussed.

Global terrorism has been described as one of the most important and pressing issues of our time (Beck, 2002; Riedel, 2011). According to a recent Gallup poll, Americans currently name "terrorism" as the most important U.S. problem superseding the formerly most important topic: "the economy" (Riffkin, 2015). Especially, the rise of the so-called IS ${ }^{1}$ has significantly affected the perception of terrorism around the world. Since the (self-) proclamation of the IS or the ISCaliphate on June 29, 2014, the worldwide coverage on the IS has been dominating the media landscape (Satti, 2015; Zhang \& Hellmueller, 2016). International news networks are extensively reporting on the vast number of atrocities, terrorist attacks, tortures, and rapes committed by proponents of the IS (Satti, 2015), which is classified as terrorist organization by the U.S. Department of State (2016) and many other international governments.

Previous research revealed that prejudices against Muslims are pervasive in Western societies (Strabac \& Listhaug, 2008) and the general media coverage of Muslims is regularly framed in negative ways (Ahmed \& Matthes, 2016; Bowe, Fahmy, \& Matthes, 2015; Bowe, Fahmy, \& Wanta, 2013; Powell, 2011; see also Matthes \& Schmuck, 2017; Schmuck \& Matthes, 2015, 2017). Especially, Muslims are regularly depicted as out-group extremists (Chuang \& Roemer, 2013; Mahony, 2010; Sides \& Gross, 2013) and are linked to terrorist acts in terrorism news (Ahmed \& Matthes, 2016; Gerhards \& Schäfer, 2014; Satti, 2015). In this context, a different line of research has demonstrated that exposure to news reports about terrorism frequently elicits fear of terrorism in news consumers (Nellis \& Savage, 2012; Slone, 2000) and generates negative attitudes toward out-groups, as for instance Arabs (Das, Bushman, Bezemer, Kerkhof, \& Vermeulen, 2009; Oswald, 2005; Stephan, Renfro, Esses, Stephan, \& Martin, 2005).

Against this background, the intensive media coverage about the IS has raised concerns about unwanted and negative effects on news consumers' perceptions of Muslim citizens living in Western societies. More precisely, an intensive debate arose over whether there is a link between Islam and terrorists of Muslim faith (e.g.,

\footnotetext{
${ }^{1}$ According to the Stanford Mapping Militant Organizations Project (2016) the IS is a Salafi militant organization in Syria and Iraq that is also known as the Islamic State in Iraq and Syria (ISIS or ISIL). Throughout this article we use the name IS to refer to this organization.
} 
Hodges, 2015), and how the news media should report about Islamist terrorists (Gerhards \& Schäfer, 2014; Sides \& Gross, 2013; Strabac \& Listhaug, 2008). According to Arciszewski, Verlhiac, Goncalves, and Kruglanski (2010), news about "Islamist terrorism" especially affects Muslims living in European countries and the United States, because non-Muslim individuals may attribute fears and threats triggered by terrorism news to Muslims as a group.

We theorize that differentiation in news reports may play an essential role in preventing negative stereotypes about out-group members such as Muslims (Sides \& Gross, 2013; Woods, 2011). Gerhards and Schäfer (2014) showed that the level of differentiation in terrorism news may significantly vary. For example, in the coverage of the 2005 terror attack in London, CNN tended to not differentiate between the Islamist terrorists and Muslims in general, describing the terrorists as "British-based radical Muslims" (Gerhards \& Schäfer, 2014, p. 14). In contrast, the pan-Arab station Al Jazeera (Qatar) clearly distinguished between terrorists and Muslims in general, for example, "Many Muslims have condemned the attacks" (Gerhards \& Schäfer, 2014, p. 12). Based on research on categorization (Hogg \& Reid, 2006), journalistic differentiation may help news consumers to clearly differentiate between potentially overlapping out-group categories. This may, especially, apply to outgroup categories that are not well differentiated in the first place (e.g., Muslims and Muslim extremists). More specifically, mass-mediated information about IS terrorism that does explicitly distinguish between Muslim terrorists and Muslims in general may result in a more differentiated perception of the out-group among non-Muslim recipients (i.e., Muslim terrorists are perceived as different from Muslims in general), preventing negative stereotypes toward Muslims. In contrast, undifferentiated news coverage (i.e., with no explicit differentiation between Muslim terrorists and the general Muslim population) may increase a non-Muslim recipient's perceived out-group homogeneity, thus increasing the perception that all Muslims are similar. This out-group homogeneity effect (Park \& Rothbart, 1982; Rothgerber, 1997) describes the general tendency to assume that outgroup members are relatively more homogeneous than in-group memebers and has been demonstrated for different areas of research such as race (e.g., Aboud, 2003; Ryan, Judd, \& Park, 1996) or nationality (e.g., Marques \& Paez, 1994). Based on this body of research, we theorize that a lack of differentiation in news coverage about Muslim terrorists may result in more negative attitudes toward Muslim citizens in general (Oswald, 2005; Sides \& Gross, 2013). However, this has not been tested so far.

This study aims to fill three important gaps. First, previous research lacks an investigation of how differentiation in news reports about Islamist terrorism affect recipients' perceptions of Muslims in general. Understanding the effects of differentiation can, however, be regarded as important insight for journalists in the newsroom. Second, fear of terrorism has been identified as an important mediator between terrorism news and particular out-group perceptions (e.g., Oswald, 2005; Slone, 2000). However, it remains unclear if 
and how differentiated, respectively, undifferentiated news reports about IS terrorism affect news consumers' fear reactions. Clarification of the underlying processes of how differentiation in the news about terrorism affects news consumers' perceptions of Muslims can be regarded highly relevant for future research and may further contribute to improving news coverage about terrorism.

Third, certain individual predispositions such as personal experiences with Muslims may bolster or, by contrast, prevent negative effects of terrorism news on attitudes toward Muslims. Yet, the conditions that may moderate the extent to which news articles about terrorism influence individuals' attitudes toward Muslims have not been addressed thus far. However, as hostile attitudes toward minority groups may severely harm intergroup relations between Muslims and non-Muslims, investigating the conditions that make individuals particularly susceptible to negative effects of terrorism news reports is of crucial importance.

Therefore, the present research used an experimental design to manipulate differentiation in the news coverage about IS terrorism. We presented different news articles dealing with IS terrorism to participants. The articles either differentiated between Muslim terrorists and the mainstream Muslim population or not. Hereby, we aimed at addressing the following three questions. First, does differentiation in news about IS terrorism affect recipients' fear of terrorism? Second, does fear of terrorism mediate the effects of article type (differentiated vs. undifferentiated) on negative attitudes toward Muslims? Third, does (positive/negative) prior personal experience with Muslims moderate the effects of fear of terrorism on negative attitudes toward Muslims?

\section{TERRORISM, NEWS COVERAGE, AND EFFECTS ON FEAR OF TERRORISM}

Scholars have pointed out that defining terrorism can be regarded a difficult task and that what particular actions qualify as terrorist acts is a challenging question (for an overview, see Cooper, 2001). However, Moghaddam and Marsella (2004) suggested that several aspects can be pointed out that all terrorist acts have in common. They named the use of violence, the intention to generate fear, and the intention to influence or change citizens' political beliefs or social positions (p. 14). Furthermore, domestic terrorism (e.g., conflicts between a specific independence or separatist movement like the Irish Republican Army or Euskadi Ta Askatasuna) can be differentiated from international or global terrorism (that the current article focuses on), which is nowadays regularly "associated to radical Islamic fundamentalists calling for Jihad and to most people directly linked to Islam and Muslims" (Arciszewski et al., 2010, p. 7). Mass 
media play an essential role in distributing information about terrorism. Especially, after the self-proclamation of the IS in 2014, the international news media have started to intensively report about IS terrorist actions (Satti, 2015; Zhang \& Hellmueller, 2016). In this context, it has been shown that the IS developed a systematic and elaborate media strategy that includes professionally produced media contents (e.g., articles, pictures, videos) that regularly appear on Western news media outlets (Farwell, 2014).

Previous research shows that news about terrorism - as intended by terrorist organizations like the IS (Cooper, 2001) - can seriously affect an individual's fear reactions (Lerner, Gonzalez, Small, \& Fischhoff, 2003). ${ }^{2}$ More precisely, news reports about terrorism can prime fear of terrorism in news consumers (Lerner et al., 2003). Priming refers to the "short-term impact of exposure to a mass-mediated stimulus on subsequent judgments" (Arendt, 2013) and particular primes may change "the standards that people use to make political evaluations" (Iyengar \& Kinder, 1987, p. 63).

In general, Nellis and Savage (2012) showed that frequency of exposure to TV news about terrorism was associated with greater fear "that a family member will be the victim of a terrorist attack" (p. 7). Dumont, Yzerbyt, Wigboldus, and Gordijn (2003) showed that exposing European participants to visual material of the $9 / 11$ attacks (Twin Towers on fire) and making them believe that they are part of the same group as the American victims of the attacks systematically increased their fear reactions. Slone (2000) demonstrated that participants exposed to a television news clip about terrorism in Israel (Hizballah and Hamas activities and terrorist attacks within Israel) experienced a significantly higher level of anxiety compared to a control group. Furthermore, Fischer, Greitemeyer, Kastenmüller, Frey, and Oßwald (2007) showed that the level of fear experienced by recipients depends on the degree of threat related information. Exposing participants to information about terrorist acts and highlighting a "currently high risk of terrorism" significantly increased recipients' fear reactions compared to the identical text in combination with information highlighting a current "low risk of terrorism."

Taken together, the reviewed results suggest that news about terrorism can systematically affect news consumers' fear reactions. However, the experienced level of fear of recipients may vary depending on the specific information provided or the way terrorism news are presented. We theorize that one characteristic of journalistic texts is crucial in that context: the level of journalistic differentiation between Muslim terrorists, on one hand, and Muslims in general, on the other.

\footnotetext{
${ }^{2}$ Fear has been described as an emotion that is negatively valenced and that is regularly accompanied by a high level of arousal. Fear is elicited by a threat that is perceived to be of high personal relevance to an individual (Lang, 1984).
} 


\section{NEWS DIFFERENTIATION: DISTINGUISHING BETWEEN MUSLIMS AND MUSLIM TERRORISTS}

Previous research suggests that differentiation can play an essential role in news reports about terrorism (Gerhards \& Schäfer, 2014; Sides \& Gross, 2013; Stephan et al., 2005; Woods, 2011). Undifferentiated reporting, also referred to as generalization, "refers to the extension of the characteristics or activities of a specific and specifiable group of people to a much more general and open-ended set" (Teo, 2000, p. 16). Differentiated reporting, in contrast, explicitly distinguishes between more general and open-ended sets (e.g., Muslims in general) and the characteristics and activities of individual people (e.g., Islamist terrorists who self-identify as Muslims). Therefore, news differentiation is defined as the differentiation between Islamist terrorism or terrorist acts committed by Muslim terrorists and Muslims or the general Muslim population living in Western countries at large.

Non-Muslim recipients exposed to news coverage about terrorism that does not differentiate between Muslims and Muslim terrorists should increase a recipient's perception that all Muslims including Muslim terrorists are similar. This is in line with social identity theory (SIT; Tajfel \& Turner, 1986), as well as the out-group homogeneity effect (Park \& Rothbart, 1982; Rothgerber, 1997). SIT predicts that in-group individuals regularly try to maintain a positive social identity by comparisons with relevant out-groups. According to SIT, social behavior can range from interpersonal to intergroup behavior along a continuum (the extreme form of each behavior is only rarely found in real life). Interpersonal behavior relates to the "interaction between two or more individuals that is fully determined by their interpersonal relationships and individual characteristics, and not at all affected by various social groups or categories to which they respectively belong" (Tajfel \& Turner, 1986, p. 277).

In contrast, the extreme form of intergroup behavior is defined as the interaction between two or more individuals (or groups of individuals) that is completely determined by their respective group memberships and not by their particular personal relationships (Tajfel \& Turner, 1986). Especially, when social behavior can be characterized as intergroup behavior, in-group individuals tend to perceive out-group members as homogenous and similar (Tajfel \& Turner, 1986).

Similarly, the out-group homogeneity effect (Park \& Rothbart, 1982; Rothgerber, 1997) predicts that persons of an in-group (e.g., non-Muslims) will perceive an out-group (e.g., Muslims) as less variable and out-group members as more similar to one another, compared to the own in-group (e.g., "they" are all alike and we-in-group - are diverse). Thus, undifferentiated (compared to differentiated) terrorism news should increase a non-Muslim individual's perceived out-group homogeneity. Perceiving Muslim terrorists and Muslims as rather similar and as jointly being part of a rather large out-group (Muslim population 
in a Western society) may affect non-Muslim individuals' perceived fear of terrorism (Ommundsen, Van der Meer, Yakushko, \& Ulleberg, 2013). The rationale behind this assumption is as follows: the larger an out-group technically is, the greater is the likelihood of being harmed by an out-group member. Rephrased, if all Muslims are perceived as terrorists, then the terrorist threat is much higher compared to the notion that Muslim terrorists are individual outsiders not associated with the Muslim majority. This is in line with previous research. According to Stephan, Ybarra, and Morrison (2009), relative group size of an out-group plays a fundamental role for intergroup perceptions. Following this, the larger an outgroup is perceived to be, the higher the respective threat perceptions for an ingroup member. Therefore, terrorism news that does not differentiate between Muslims in general (e.g., Muslim citizens living in a Western city) and individual Islamist terrorists should increase the perceived group size of the out-group, hence increasing non-Muslim individuals' fear of terrorism. In contrast, recipients exposed to differentiated news about terrorism should perceive the particular group size of the out-group to be smaller and will thus experience lower levels of fear of terrorism. Hence, we assume that both undifferentiated and differentiated news about IS terrorism will prime individuals' fear of terrorism. However, based on the theoretical reasoning just outlined, we expect that the former will have a stronger effect on fear of terrorism than the latter.

More formally, $\mathrm{H} 1$ and $\mathrm{H} 2$ read as follows:

H1: Participants exposed to (a) undifferentiated and (b) differentiated news about IS terrorism will experience an increased level of fear of terrorism compared to participants in the control group.

H2: Participants exposed to an undifferentiated news coverage about IS terrorism will experience a higher level of fear of terrorism compared to participants exposed to a differentiated news coverage.

\section{EFFECTS OF FEAR OF TERRORISM ON HOSTILE ATTITUDES TOWARD MUSLIMS}

According to intergroup threat theory (Stephan et al., 2009) perceptions of threat may significantly affect how individuals perceive an out-group or out-group members. Intergroup threat theory differentiates between two types of threats - symbolic and realistic threats (Stephan et al., 2009; for an earlier version of the theory labeled integrated threat theory, see Stephan \& Stephan, 2000). Symbolic threats comprise threats to a group's values, beliefs, and worldviews, as well as individual threats such as undermining an individual's self-identity or self-esteem. Realistic threats are threats to a group's resources and general welfare, as well as threats to an individual 
like "actual physical or material harm, pain, torture, death, economic loss and threats to health or personal security" (Stephan et al., 2009, p. 44f.)

Empirical findings have supported the assumptions of the theory and shown that threat perceptions, respectively, fear of terrorism affects non-Muslim recipients' attitudes and hostile perceptions toward Muslims in general (Das et al., 2009; Lerner et al., 2003; Oswald, 2005; Stephan et al., 2005). Oswald (2005) showed that fear of terrorism is directly related to non-Muslim persons' hostile perceptions of Muslims in general, and Stephan et al. (2005) demonstrated that negative out-group perceptions were particularly strong when an out-group posed both realistic and symbolic threats.

One may argue that IS terrorism communicated via the news media poses both realistic and symbolic threats to news consumers and may thus result in particularly negative out-group perceptions. "Muslims in European countries (as well as in the United States) will be the first target" (p. 14) of such negative outgroup perceptions because "fears and threats created by terrorism can be attributed to Muslims as a group" (Arciszewski et al., 2010, p. 7). Based on this reasoning, $\mathrm{H} 3$ reads as follows:

\section{H3: A higher fear of terrorism will result in more hostile attitudes toward Muslims.}

It has been proposed that intergroup contact (contact hypothesis) may improve ingroup individuals' out-group attitudes (Pettigrew, 1998). Superficial and simple forms of contact tend to be ineffective (Hewstone $\&$ Brown, 1986) or may even result in more negative evaluations of the out-group, when respective contact is negative (Islam \& Hewstone, 1993). However, more intensive positive experiences with out-group members (e.g., at the workplace) can improve attitudes toward the out-group at large (Brown, Vivian, \& Hewstone, 1999; Voci \& Hewstone, 2003), because individuals of an in-group "generalize positive attitudes promoted by the contact experience to include other members of the out-group not actually present in the contact situation" (Hewstone, 1996, p. 328).

The literature contains two prevalent models that make opposite predictions on how contact may/may not result in generalization, respectively, in positive effects toward out-group members not present in a contact situation. According to the decategorized contact model (DCM; Brewer \& Miller, 1984) it is unlikely that contact to individuals of an out-group will result in a positive generalization to the out-group at large. The DCM predicts that positive contact of an in-group person will result in "decategorization" decreasing the salience of the out-group interactant's group membership while increasing the salience of his or her unique individual characteristics. Thus, a "non-category-based interaction" usually results in the perception that a particular person is an "exception to the rule" and that she or he is not a typical representative of the larger out-group (e.g., she or he is a nice person, but all other Muslims are not). In contrast, the mutual intergroup differentiation 
model (Hewstone, 1996; Hewstone \& Brown, 1986) predicts that positive contact results in positive generalization when the original group membership of interactants' is preserved. Thus, it is important that in-group individuals have to be more or less aware of the out-group membership of an out-group interactant. In this context, Voci and Hewstone (2003, Experiment 1) showed that rather low levels of out-group salience were sufficient to generate respective positive out-group effects.

What remains unclear in this connection is, if positive prior contact with out-group individuals can mitigate negative out-group generalizations triggered by fear inducing media coverage. Previous research has mainly focused on the question of how positive contact between in-group and out-group individuals may or may not result in more positive attitudes toward the out-group at large. What has not been systematically studied in this context is, if positive real-life experiences with out-group members can alleviate potential hostile perceptions toward the out-group at large when negative media information is available. Islam and Hewstone (1993) showed that positive prior experiences (contact) were positively and particular negative prior experiences were negatively associated with attitude toward the out-group. However, what happens when in-group individuals with positive prior out-group experiences are confronted with threatening out-group media coverage? Can positive prior contact mitigate negative generalizations toward the out-group at large? Or does positive prior contact have no respective mitigating effects on out-group generalization? Based on this, we examine how positive prior experience moderates the particular influence of fear of terrorism on hostile perceptions toward Muslims with the help of the following research question.

RQ: How does positive prior experience with Muslims moderate the influence of fear of terrorism on hostile perceptions toward Muslims?

\section{METHOD}

We conducted a lab experiment with 103 participants. ${ }^{3}$ We employed a betweensubjects design with three experimental conditions. Participants were randomly assigned to the three conditions: three undifferentiated news articles about terrorism $(n=35)$, three otherwise identical differentiated news articles about terrorism $(n=34)$, and a control group that was exposed to three neutral news articles with no relation to the topic of terrorism $(n=34)$. A randomization check for age, $F(2)=.06$, $n s$; gender, $\chi^{2}$ $(2)=2.94, n s$; immigration background, $\chi^{2}(4)=4.71, n s$; and political predisposition, $F$ (2) $=.03, n s$, was successful.

\footnotetext{
${ }^{3}$ The original sample consisted of 172 individuals. A second experimental factor had to be dropped from the analysis due to errors in the stimuli. In addition, we excluded one participant who indicated to be Muslim. This resulted in a total remaining sample of 103 participants.
} 


\section{Procedure}

The experiment was conducted at the research laboratory of the Department of Communication at the University of Vienna, Austria. After prior informed consent, participants took part in the experiment in groups of a maximum of eight people. Each participant took a seat in front of one of the eight computers. During the study, participants were separated from each other by nontransparent, noise-absorbing dividers. They were randomly assigned to one of the stimulus conditions. In total, they read three newspaper articles, which were presented on a blank screen. Exposure time was not forced. ${ }^{4}$ Participants were instructed to read the articles carefully. The stimulus presentation was followed by the assessment of the dependent variables. Upon completion, participants were thanked and debriefed.

\section{Participants}

Participants were 103 non-Muslim students (76\% female) ages 19-39 $(M=21.95, S D=2.76)$ enrolled in an introduction course on communication research at the University of Vienna. Of all participants, $63.1 \%$ had no immigrant background, $20.4 \%$ were second-generation immigrants, and $16.5 \%$ were firstgeneration immigrants; all participants were fluent in German (political orientation $M=4.45, S D=1.72 ; 10$-point scale from 1 [extremely left] to 10 [extremely right]). They received extra course credit for participation.

\section{Stimulus Material}

Based on existing news articles about Islamist terrorism, three news articles (described next) about attempted terrorist attacks or other activities by the IS were created for each condition. We used three articles in each condition because it has been argued that using different media exemplars increases the external validity of experimental media effects studies (Reeves, Yeykelis, \& Cummings, 2016). The news articles were designed as online news articles of the web portal of the two biggest Austrian quality newspapers-Der Standard (derstandard.at) and Die Presse (diepresse.com) — and a large Austrian tabloid newspaper, Kurier (kurier.at). The articles were elaborately designed (layout, colors, newspaper logos, typography) to make them look like authentic news articles that had actually been published on the web portals of the three online newspapers. All articles had between 250 and 300 words. In addition to the stories' hard facts

\footnotetext{
${ }^{4}$ Participants could decide how long the exposure time to a news article would be. Overall time to read the news articles was entered into the model as covariate in an additional analysis. Reading time had no influence on fear of terror $(b=-0.03, S E=0.12, p=.79)$, or hostile attitudes toward Muslims $(b=0.07$, $S E=0.08, p=.37$ ). Also, the significant effects depicted in Table 1 did not change after exposure time was controlled.
} 
(identical in each of the story versions), all articles' contained an expert's statement, which either stressed the difference between the mainstream Muslim population in Austria and Islamist terrorists or did not explicitly make this distinction (see the appendix).

The first article dealt with a planned terrorist attack by the IS in Vienna that could be prevented by arresting the terrorist. The article contained a statement by a fictitious jihadism expert who commented the events by either stressing the difference between a few jihadists and the mainstream Muslim population in the differentiated version or describing that more and more young Muslims from the general population are drawn into jihadism. The second article described a warning by Europol that rated the danger of a terrorist attack by the IS in Vienna as high. In addition, the article contained a comment by the director of Europol, who mentioned in the undifferentiated version that terrorism is a danger that has its roots in the center of the Muslim society in Western European countries such as Austria. In the differentiated version, he stated that Muslims in Austria are an important help for Austrian authorities in the war against terrorism. Finally, the third article dealt with the illegal smuggle of passports in Austria. The text described that the IS uses false passports to illegally send terrorists into the country. This article contained an additional statement by a fictitious Islam expert in which he warns of a generalization from Muslim extremists to peaceful Muslims who are not involved in these incidents in the differentiated version of the article. In the undifferentiated version, the expert mentions that the Islam religion and its organizations have a problem with violence that has to be dealt with. All other passages of the articles remained unchanged, and participants in the experimental conditions were thus exposed to the identical general information.

Participants in the control group were exposed to three unrelated articles with no cue to terrorism, Islam, or immigration. The three articles dealt with pregnancy, tourism, and school students' homework. The articles were original news articles published in the same three news outlets as the treatment articles. The articles were slightly changed to resemble the other articles in length and structure.

\section{Pretest of Stimulus Material}

A pretest of the stimulus material was conducted with an independent sample $\left(N=52,58 \%\right.$ female, $\left.M_{\text {age }}=22.67, S D=5.54\right)$. All items were assessed on a Likert-type scale from 1 (strongly disagree) to 7 (strongly agree). Perceived differentiation of the news coverage was measured with three items: "The news articles clearly distinguish between Muslim terrorist and Muslims in general," "The news articles stress that Islam and Islamism need to be distinguished," and "The news articles emphasize that Muslims in general strongly oppose Islamist terrorism" (Cronbach's $\alpha=.65, M=2.13$, 
$S D=0.06)$. Results clearly indicated that perceived differentiation was rated significantly higher in the differentiated news articles $(M=4.49, S D=1.65)$ than in the undifferentiated news articles $(M=1.9, S D=0.93), F(1$, $50)=49.31, p<.001, \eta^{2}=.50$. In addition, participants completed three items assessing the perceived quality of the articles. The news articles were rated as equally credible (undifferentiated $M=3.44, S D=1.12$, differentiated $M=3.52, S D=0.71), F(1,50)=0.08, p=.774, \eta^{2}=.00$, and equally comprehensible (undifferentiated $M=4.15, S D=1.39$, differentiated $M=4.25, S D=0.60), F(1,50)=0.12, p=.728, \eta^{2}=.00$. Furthermore, perceived journalistic quality did not significantly differ between the news articles (undifferentiated $M=3.26, S D=1.12$, differentiated $M=3.31$, $S D=0.66), F(1,50)=0.03, p=.855, \eta^{2}=.00$. The ratings of all articles were thus close to the mean value.

\section{Measures}

All items were measured on a 7-point Likert-type scale from 1 (strongly disagree) to 7 (strongly agree). Fear of terrorism was gauged using three items based on Fischer and colleagues (2007) ("How high do you rate the probability that a terrorist attack may occur in Vienna within the next 12 months?" "How high do you rate the probability that you could become a victim of a terrorist attack?" "I fear that a terrorist attack could occur near me"; Cronbach's $\alpha=.75, M=3.40, S D=0.70$ ). Hostile attitudes toward Muslims were assessed with seven items based on scales by Lee, Gibbons, Thompson, and Timani (2009) and Park, Felix, and Lee (2007) ("If possible, I would avoid going to places where Muslims would be," "If I could, I would avoid contact with Muslims," "If I could, I would live in a place where there were no Muslims," "Muslims should not be allowed to work in places where many Austrians gather such as airports," "Muslims lack the ability to think independently; they follow their leaders like sheep," "Muslims want to take over the world," "I believe that Muslims support violence against non-Muslims"; Cronbach's $\alpha=.89, M=1.84$, $S D=0.33)^{5}$. Analyses of the scale's factor structure supported a unidimensional scale.

We assessed both quantitative and qualitative aspects of personal real-life contact with Muslims based on Voci and Hewstone (2003). Frequency of personal contact with Muslims was assessed with the item "In general, how frequently are you personally in contact with Muslims?" from 1 (never) to 7 (very frequently). Quality of prior contact experiences was gauged with the item "How would you rate your personal contact with Muslims thus far?" from 1 (very negative) to 7 (very positive).

\footnotetext{
${ }^{5}$ The scale represents a very conservative assessment of negative attitudes toward Muslims. Items' mean values and standard deviations in this study are comparable to those of the original scale (see Lee et al., 2009).
} 


\section{Data Analysis}

To test our hypotheses and find an answer to our research question, we conducted a moderated mediation model using the PROCESS macro in SPSS. Experimental condition was dummy coded with the control group as reference group. Fear of terrorism was modeled as mediator of the newspaper articles' effects on hostile attitudes toward Muslims. Prior experience with Muslims was modeled as moderator (Figure 1 shows the full theoretical model). The interaction term between fear of terrorism and prior experience with Muslims was modeled by including their multiplicative term. Fear of terrorism and prior experiences with Muslims were mean centered prior to computing the product (Hayes, 2013). The $95 \%$ biascorrected bootstrap confidence intervals based on 10,000 bootstrap samples were used for statistical inference of indirect effects. The frequency of contact with Muslims was controlled in all analyses to ensure that the quality of contact with Muslims was assessed independently of the contact frequency.

\section{RESULTS}

First, we investigated the effects of differentiation in news coverage about the IS on individuals' fear of terrorism (H1). Results revealed a positive and significant effect of the undifferentiated news articles on fear of terrorism compared to the control group $(b=0.68, S E=0.32, p=.035)$. The differentiated news articles, in contrast, had no significant effect on fear of terrorism $(b=0.47, S E=0.32$, $p=.141$; see Table 1 ). Thus, news coverage that clearly differentiates between Muslim terrorists and Muslims in general does not enhance individuals' general fear of terrorism. In contrast, exposure to articles that lack such a differentiation

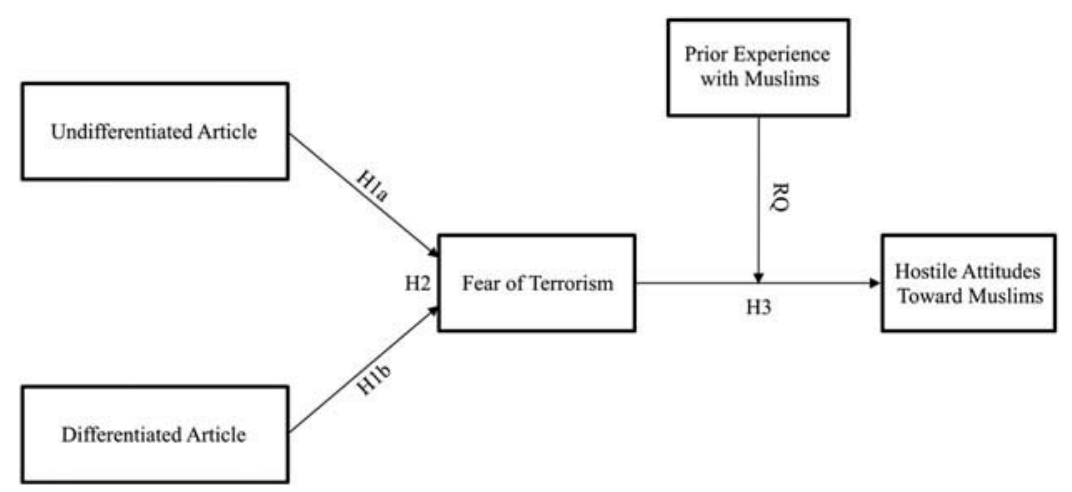

FIGURE 1 Theoretical model. 
activates higher fear of terrorism (see Table 2 for mean values). This supports H1a and contradicts H1b.

Our second hypothesis postulated that undifferentiated news articles would exert a stronger effect on fear of terrorism than the effects of the differentiated news articles. To test this hypothesis we recoded our dummy variables with differentiated news articles as reference group and repeated the analysis (not shown here). Findings revealed that although the effect of the undifferentiated articles on fear of terrorism was stronger than the one of the differentiated articles, this difference lacked statistical significance $(b=0.20, S E=0.32$, $p=.682$ ). Thus, $\mathrm{H} 2$ has to be rejected. That means, although we- by trend-

TABLE 1

Ordinary Least Squares Path Analysis, Unstandardized Coefficients

\begin{tabular}{|c|c|c|c|c|c|c|}
\hline \multirow[b]{2}{*}{ Variables } & \multicolumn{3}{|c|}{$\begin{array}{l}\text { Fear of } \\
\text { Terrorism }\end{array}$} & \multicolumn{3}{|c|}{$\begin{array}{c}\text { Hostile Attitudes Toward } \\
\text { Muslims }\end{array}$} \\
\hline & $b$ & $S E$ & $\beta$ & $b$ & $S E$ & $\beta$ \\
\hline Undifferentiated news coverage & 0.68 & 0.32 & $.24 *$ & 0.18 & 0.22 & .08 \\
\hline Differentiated news coverage & 0.47 & 0.32 & .17 & 0.09 & 0.22 & .04 \\
\hline Frequency of contact with Muslims & 0.00 & 0.08 & .00 & 0.04 & 0.06 & .07 \\
\hline Fear of terrorism & & & & 0.19 & 0.07 & $.24 * *$ \\
\hline Prior experience with Muslims & & & & -0.39 & 0.07 & $-.46^{* * *}$ \\
\hline Fear of terrorism $\times$ Prior experience with Muslims & & & & -0.10 & 0.05 & $-.16^{\dagger}$ \\
\hline Adj. $R^{2}$ & .05 & & & .34 & & \\
\hline$F$ for change in Adj. $R^{2}$ & 1.61 & & & $8.28^{* *}$ & & \\
\hline
\end{tabular}

Note. $N=103$.

${ }^{\dagger} p<.10 .{ }^{*} p<.05 .{ }^{* *} p<.01 .{ }^{* * *} p<.001$.

TABLE 2

Mean Values of Dependent Variables for Different Experimental Conditions

\begin{tabular}{|c|c|c|c|}
\hline & Control $^{a}$ & $\begin{array}{c}\text { Undifferentiated News } \\
\text { Articles }^{b}\end{array}$ & $\begin{array}{c}\text { Differentiated News } \\
\text { Articles }^{c}\end{array}$ \\
\hline Variable & $M(S D)$ & $M(S D)$ & $M(S D)$ \\
\hline Fear of terrorism & $3.01(1.26)$ & $3.69(1.37)$ & $3.48(1.27)$ \\
\hline $\begin{array}{l}\text { Hostile attitudes toward } \\
\text { Muslims }\end{array}$ & $1.61(0.89)$ & $1.99(1.26)$ & $1.97(1.00)$ \\
\hline
\end{tabular}

Note. $N=103$.

${ }^{\mathrm{a}} n=34 .{ }^{\mathrm{b}} n=35 .{ }^{\mathrm{c}} n=32$. 
observed a respective difference between the differentiated and undifferentiated article, this difference was not statistically significant.

Next, we investigated whether fear of terrorism increased hostile attitudes toward Muslims (H3). This was the case. The findings showed that fear of terrorism positively and significantly predicted hostile attitudes toward Muslims $(b=0.19, S E=0.07, p<.001)$, which supports H3 (see Table 1). Furthermore, we tested whether this relationship was moderated by prior experiences with Muslims. We found a close-to-significant moderation effect of prior experience with Muslims on the effect of fear of terrorism on hostile attitudes toward Muslims $(b=-0.10, S E=0.05, p=.056)$. Using Moderated Mediation analysis (Model 14 in PROCESS), we investigated the indirect effect of the undifferentiated news article on hostile attitudes toward Muslims via fear of terrorism at different levels of the moderator (the mean and $\pm 1 S D$ from the mean). Findings revealed that fear of terrorism mediated the effects of the undifferentiated news coverage on hostile attitudes toward Muslims for individuals with less positive experiences toward Muslims (indirect effect of exposure: $b=0.22, S E=0.13$ ), confidence interval (CI) $[.02, .56]$, and moderately positive experiences (indirect effect of exposure: $b=0.13, S E=0.08$ ), CI $[.01, .34]$. However, for individuals with very positive prior experiences with Muslims, we found no significant mediation effect of fear of terrorism on hostile attitudes toward Muslims (indirect effect of exposure: $b=0.04, S E=0.06$ ), CI [-.04, .25]. These results indicate that extremely positive encounters with Muslims prevent the transfer of fear of terrorism on hostile attitudes toward Muslims (Index of Moderated Mediation $=-0.07, S E=0.05), \mathrm{CI}[-.21,-.00]$. Hence, answering our research question (How does positive prior experience with Muslims moderate the influence of fear of terrorism on hostile perceptions toward Muslims?), we find that fear of terrorism only enhanced hostile attitudes toward Muslims for individuals with less positive and moderately positive prior experiences with Muslims. For those with very positive experiences, no such relationship was found (see Figure 2).

Overall, we found no direct effects of the undifferentiated news articles $(b=0.18, S E=0.22, p=.430)$ or the differentiated news articles $(b=0.09$, $S E=0.22, p=.70$ ) on hostile attitudes toward Muslims. Prior experience with Muslims had a strong negative direct effect on hostile attitudes toward Muslims $(b=-0.39, S E=0.07, p<.001)$. Finally, frequency of contact with Muslims had no effect on fear of terror $(b=0.00, S E=0.08, p=.964)$ or hostile attitudes toward Muslims $(b=0.04, S E=0.06, p=.446)$. In total, the predictors explained $5 \%$ of the variance of fear of terror and $34 \%$ of the variance of hostile attitudes toward Muslims (see Table 1). 


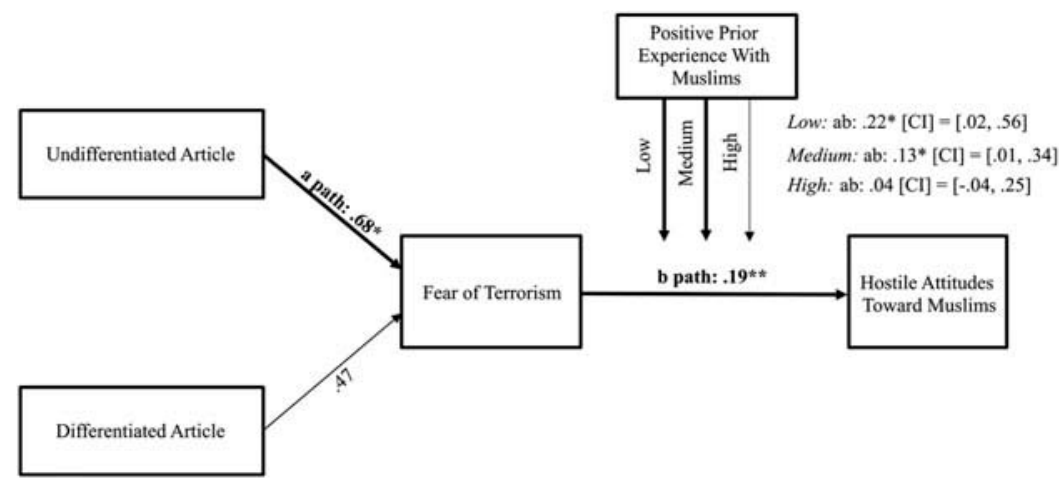

FIGURE 2 Moderated mediation model showing the indirect effects of the undifferentiated article on hostile attitudes toward Muslims via fear of terrorism for individuals with low, medium, and high positive prior experiences with Muslims. Unstandardized beta coefficients are shown, $95 \%$ biascorrected bootstrap confidence intervals based on 10,000 bootstrap samples are shown for indirect effects. Bold lines indicate significant effects. ${ }^{*} p<.05 .{ }^{* *} p<.01 .{ }^{* * *} p<.001$.

\section{DISCUSSION}

This study examined the role of differentiation in news articles about IS terrorism. In line with intergroup threat theory (Stephan et al., 2009), the results revealed that undifferentiated news about IS terrorism indirectly affected participants' attitudes toward the general Muslim population in a negative way. Fear of terrorism operated as a mediator. That is, participants exposed to undifferentiated news experienced an increased level of fear of terrorism, and these fear reactions negatively influenced a participant's attitudes toward Muslims. In contrast, this relationship between exposure and hostile attitudes toward Muslims could not be detected for individuals exposed to differentiated news about IS terrorism.

Therefore, the results of the present study corroborate and extend earlier findings on the effects of fear of terrorism showing that terrorism news increase news consumers' fear reactions (e.g., Das et al., 2009; Oswald, 2005; Slone, 2000; Stephan et al., 2005). However, in these previous studies participants were assigned to specific terrorism stimuli (fear evoking news) or a control condition (exposure to an unrelated and non-fear-evoking topic) in order to examine particular effects of terrorism news on a superordinate level. The present study extended this line of research and did not only examine effects of terrorism news per se. Particular effects were analyzed in a more 
nuanced way showing that terrorism news does not necessarily have to increase a recipient's fear of terrorism, and that differentiation within the news played a crucial role in this context. In line with this reasoning, another central finding of the study relates to participants' prior experiences with Muslims. We found no significant mediation effect of fear of terrorism on hostile attitudes toward Muslims for participants who reported very positive prior experiences with Muslims. However, fear of terrorism enhanced hostile attitudes toward Muslims for both individuals with less positive and moderately positive prior experiences with Muslims.

These results indicate that hostile attitudes toward Muslims in connection with terrorism news can be prevented in two ways. First, although differentiated news reporting can be regarded relevant in general, it apparently is a necessary prerequisite for individuals with less positive or moderately positive prior experiences with Muslims. For those individuals, differentiation has to be realized within the news. Second, very positive prior experiences may avoid hostile attitudes toward Muslims in response to undifferentiated news. Individuals with very positive prior experiences with Muslims are obviously capable of differentiating between Muslims and Muslim terrorists - in form of a mental process - even when they are exposed to undifferentiated news about terrorism. That is, because they made positive prior experiences with Muslims, they are immune against generalizing terror news to all Muslims. This extends previous research on categorization and out-group attitudes (Hewstone, 1996; Hewstone \& Brown, 1986; Islam \& Hewstone, 1993) showing that positive out-group contact may not only result in positive generalizations toward the out-group at large but also buffer against negative media effects on hostile out-group attitudes. Furthermore, this finding underlines the importance of news differentiation in the context of terrorism news, because non-Muslim individuals' views of Muslims are generally rather negative (Strabac \& Listhaug, 2008) and a large share of non-Muslims is not in regular communication with Muslims, thus decreasing the likelihood of very positive real-life experiences (Kalkan, Layman, \& Uslaner, 2009).

Furthermore, our data clearly show that positive prior experiences could not prevent the activation of fear of terrorism in response to the undifferentiated news article. An additional analysis revealed no significant interaction effect between news differentiation and prior experiences on fear of terrorism $(b=-.02, S E=.22, p=.926)$. Thus, this finding additionally confirms that very positive experiences can only prevent the transfer of fear of terrorism on attitudes toward Muslims. Fear in response to the undifferentiated article, however, is evoked among all individuals irrespectively of their prior experiences. Prior experiences can thus help to cope with fear, rather than preventing fear in the first place. 
It is important to note that the two news conditions did not differ significantly from each other. Yet the undifferentiated condition had a significant effect compared to the control group, the differentiated condition did not. That is, although there were differences in statistical significance compared to the control group, this difference itself was not significant (although clearly pointing into the expected direction). One explanation for this could be the rather conservative manipulation used in the undifferentiated versions of our stimulus articles. Although participants were exposed to three articles, each article consisted of only one modified statement at the end of the particular article (see the appendix), whereas the rest of the information remained unchanged. However, news articles may contain numerous and much stronger hints or cues to potential links between Islam and radical Muslims. For example, the central theme of an article can deal with this aspect, and these links may be incorporated into a news article much more prominently (in the headline of a news article, e.g., "There is a clear link between Islam and terrorism"; see Hodges, 2015). Thus, one may argue that the detected effects in our study were realized under rather conservative conditions and one may expect even stronger effects in "real life." Furthermore, the effects of frequent exposure to undifferentiated (differentiated) news may add up, thus resulting in powerful effects across time (Abelson, 1985). Irrespective of this explanation, we can still interpret the statistically significant effect of the undifferentiated condition on fear, and we can conclude that differentiated news does not significantly evoke fear. This is in line with our theoretical reasoning.

There are notable limitations. First, future studies should try to replicate the present findings outside a forced exposure setting (see de Vreese \& Neijens, 2016) and using different samples (e.g., older and less educated participants) and larger sample sizes. Second, participants in the present study were exposed to online news articles. Although we used several articles, as well as both quality and tabloid online newspapers as news outlets, future studies may use different news outlets (e.g., television), thus testing if the effects can be generalized. One may argue that a combination of textual/verbal and visual information may result in even stronger effects, because differentiated or undifferentiated information can be depicted more vividly using, for example, text and visuals. However, this is an empirical question and should be analyzed in future approaches. Third, we tested effects of differentiation on participants' fear reactions and respective out-group perceptions only. However, one may argue that reporting about terrorism in an undifferentiated/differentiated way may affect several other outcome variables including an individual's perceived news credibility. The rationale behind this assumption is that recipients may regard high levels of differentiation (compared to a low level of differentiation) depicted in a news article as a quality indicator increasing the perceived credibility of a news coverage or a news outlet. We can clearly rule out this explanation in our study: The pretest demonstrated that both versions were rated as equally credible. But future 
examinations should additionally test this theoretically important assumption. Fourth, future studies should examine the moderating effects of positive prior contact with Muslims in depth. Especially, examining the role of group salience, for example, how salient does a respective out-group membership have to be during interaction to result in positive generalizations toward the out-group, and how specific prior experiences interact with particular information provided by the news media would be valuable new avenues for future research.

\section{CONCLUSION}

The news media frequently and intensively report about terrorism news including attacks or attempted attacks by IS terrorists (Satti, 2015; Zhang \& Hellmueller, 2016). Of course, news reports of this kind are valuable and important information for the public's understanding of certain issues at stake and can be regarded a cornerstone for free and democratic decision making. However, this type of news coverage can come with serious consequences, namely, negative out-group perceptions of Muslims in general and may further enhance intergroup conflicts between Muslims and non-Muslims. Differentiated news reporting may dissolve this dilemma. When journalists in the newsroom clearly and explicitly distinguish between news about Muslims and Islamist terrorism, this may result in a win-win situation. Citizens are being informed about serious issues at stake, whereas unwanted generalizations resulting in hostile attitudes toward Muslims are avoided.

\section{REFERENCES}

Abelson, R. P. (1985). A variance explanation paradox: When a little is a lot. Psychological Bulletin, 97(1), 129-133. doi:10.1037/0033-2909.97.1.129

Aboud, F. E. (2003). The formation of in-group favoritism and out-group prejudice in young children: Are they distinct attitudes? Developmental Psychology, 39(1), 48-60. doi:10.1037/00121649.39.1.48

Ahmed, S., \& Matthes, J. (2016). Media representation of Muslims and Islam from 2000 to 2015: A meta-analysis. International Communication Gazette, 79(3), 219-244. doi:10.1177/ 1748048516656305

Arciszewski, T., Verlhiac, J.-F., Goncalves, I., \& Kruglanski, A. (2010). From psychology of terrorists to psychology of terrorism. Revue Internationale de Psychologie Sociale, 22(3), 5-34. Retrieved from http://www.cairn.info/article.php?ID_ARTICLE=RIPSO_223_0005

Arendt, F. (2013). Dose-dependent media priming effects of stereotypic newspaper articles on implicit and explicit stereotypes. Journal of Communication, 63(5), 830-851. doi:10.1111/jcom.12056

Beck, U. (2002). The terrorist threat. World risk society revisited. Theory, Culture \& Society, 19(4), 39-55. doi:10.1177/0263276402019004003

Bowe, B. J., Fahmy, S., \& Matthes, J. (2015). U.S. newspapers provide nuanced picture of Islam. Newspaper Research Journal, 36(1), 42-57. doi:10.1177/073953291503600104 
Bowe, B. J., Fahmy, S., \& Wanta, W. (2013). Missing religion: Second level agenda setting and Islam in American newspapers. International Communication Gazette, 75(7), 636-652. doi:10.1177/ 1748048513482544

Brewer, M. B., \& Miller, N. (1984). Beyond the contact hypothesis: Theoretical perspectives on desegregation. In N. Miller \& M. B. Brewer (Eds.), Groups in contact: The psychology of desegregation (pp. 281-302). Orlando, FL: Academic Press.

Brown, R., Vivian, J., \& Hewstone, M. (1999). Changing attitudes through intergroup contact: The effects of group membership salience. European Journal of Social Psychology, 29(5-6), 741-764. doi:10.1002/(SICI)1099-0992(199908/09)29:5/6<741::AID-EJSP972>3.0.CO;2-8

Chuang, A., \& Roemer, R. C. (2013). The immigrant Muslim American at the boundary of insider and outsider: Representations of Faisal Shahzad as "homegrown" terrorist. Journalism \& Mass Communication Quarterly, 90(1), 89-107. doi:10.1177/1077699012468740

Cooper, H. H. A. (2001). Terrorism: The problem of definition revisited. American Behavioral Scientist, 44(6), 881-893. doi:10.1177/00027640121956575

Das, E., Bushman, B. J., Bezemer, M. D., Kerkhof, P., \& Vermeulen, I. E. (2009). How terrorism news reports increase prejudice against outgroups: A terror management account. Journal of Experimental Social Psychology, 45(3), 453-459. doi:10.1016/j.jesp.2008.12.001

de Vreese, C. H., \& Neijens, P. C. (2016). Measuring media exposure in a changing communications environment. Communication Methods and Measures, 10(2-3), 69-80. doi: 10.1080/ 19312458.2016.1150441

Dumont, M., Yzerbyt, V., Wigboldus, D., \& Gordijn, E. H. (2003). Social categorization and fear reactions to the September 11th terrorist attacks. Personality and Social Psychology Bulletin, 29 (12), 1509-1520. doi:10.1177/0146167203256923

Farwell, J. P. (2014). The Media Strategy of ISIS. Survival, 56(6), 49-55. doi:10.1080/ 00396338.2014 .985436

Fischer, P., Greitemeyer, T., Kastenmüller, A., Frey, D., \& Oßwald, S. (2007). Terror salience and punishment: Does terror salience induce threat to social order? Journal of Experimental Psychology, 43(6), 946-971. doi:10.1016/j.jesp.2006.10.004

Gerhards, J., \& Schäfer, M. S. (2014). International terrorism, domestic coverage? How terrorist attacks are presented in the news of $\mathrm{CNN}$, Al Jazeera, the $\mathrm{BBC}$, and $\mathrm{ARD}$. International Communication Gazette, 76(1), 3-26. doi:10.1177/1748048513504158

Hayes, A. F. (2013). Introduction to mediation, moderation, and conditional process analysis: A regression-based approach. New York, NY: Guilford Press.

Hewstone, M. (1996). Contact and categorization: Social psychological interventions to change intergroup relations. In C. N. Macrae, C. Stangor, \& M. Hewstone (Eds.), Stereotypes and stereotyping (pp. 323-368). New York, NY: Guilford Press.

Hewstone, M., \& Brown, R. J. (1986). Contact is not enough: An intergroup perspective on the contact hypothesis. In M. Hewstone, \& R. J. Brown (Eds.), Contact and conflict in intergroup encounters (pp. 1-44). Oxford, UK: Blackwell.

Hodges, D. (2015). There is a clear link between Islam and terrorism. It's up to all of us to break it. Retrieved from http://www.telegraph.co.uk/news/uknews/terrorism-in-the-uk/12007852/There-is-aclear-link-between-Islam-and-terrorism.-Its-up-to-all-of-us-to-break-it.html

Hogg, M. A., \& Reid, S. (2006). Social identity, self-categorization, and the communication of group norms. Communication Theory, 16(1), 7-30. doi:10.1111/j.1468-2885.2006.00003.x

Islam, M. R., \& Hewstone, M. (1993). Dimensions of contact as predictors of intergroup anxiety, perceived outgroup variability, and outgroup attitude: An integrative model. Personality \& Social Psychology Bulletin, 19(6), 700-710. doi:10.1177/0146167293196005

Iyengar, S., \& Kinder, D. R. (1987). News that matters: Television and American opinion. Chicago, IL: Chicago University Press. 
Kalkan, K. O., Layman, G. C., \& Uslaner, E. M. (2009). "Bands of others"? Attitudes toward Muslims in contemporary American Society. Journal of Politics, 71(3), 847-862. doi:10.1017/ S0022381609090756

Lang, P. J. (1984). Cognition in emotion: Concept and action. In C. E. Izard, J. Kagan, \& R. B. Zajonc (Eds.), Emotions, cognition, and behavior (pp. 192-226). Cambridge, UK: Cambridge University Press.

Lee, S. A., Gibbons, J. A., Thompson, J. M., \& Timani, H. S. (2009). The Islamophobia Scale: Instrument development and initial validation. The International Journal for the Psychology of Religion, 19(2), 92-105. doi:10.1080/10508610802711137

Lerner, J. S., Gonzalez, R. M., Small, D. A., \& Fischhoff, B. (2003). Effects of fear and anger on perceived risk of terrorism. Psychological Science, 14(2), 144-150. doi:10.1111/14679280.01433

Mahony, I. (2010). Diverging frames: A comparison of Indonesian and Australian press portrayals of terrorism and Islamic groups in Indonesia. International Communication Gazette, 72(8), 739-758. doi:10.1177/1748048510380813

Marques, J. M., \& Paez, D. (1994). The 'black sheep effect': Social categorization, rejection of ingroup deviates, and perception of group variability. European Review of Social Psychology, 5(1), 37-68. doi:10.1080/14792779543000011

Matthes, J., \& Schmuck, D. (2017). The effects of anti-immigrant right-wing populist ads on implicit and explicit attitudes: A moderated mediation model. Communication Research, 44(4), 556-581. doi:10.1177/0093650215577859

Moghaddam, F. M., \& Marsella, A. J. (Eds.). (2004). Understanding terrorism: Psychological roots, consequences, and interventions. Washington, DC: American Psychological Association.

Nellis, A. M., \& Savage, J. (2012). Does watching the news affect fear of terrorism? The importance of media exposure on terrorism fear. Crime \& Delinquency, 58(5), 748-768. doi:10.1177/ 0011128712452961

Ommundsen, R., Van der Meer, K., Yakushko, O., \& Ulleberg, P. (2013). Exploring the relationship between fear-related xenophobia, perceptions of out-group entitativity, and social contact in Norway. Psychological Reports, 112(1), 109-124. doi:10.2466/17.07.21.PR0.112.1.109-124

Oswald, D. L. (2005). Understanding anti-Arab reactions post 9/11: The role of threats, social categories, and personal ideologies. Journal of Applied Social Psychology, 35(9), 1775-1799. doi:10.1111/j.1559-1816.2005.tb02195.x

Park, B., \& Rothbart, M. (1982). Perception of out-group homogeneity and levels of social categorization: Memory for the subordinate attributes of in-group and out-group members. Journal of Personality and Social Psychology, 42(6), 1051-1068. doi:10.1037/0022-3514.42.6.1051

Park, J., Felix, K., \& Lee, G. (2007). Implicit attitudes toward Arab-Muslims and the moderating effects of social information. Basic and Applied Social Psychology, 29(1), 35-45. doi:10.1080/ 01973530701330942

Pettigrew, T. F. (1998). Intergroup contact theory. Annual Review of Psychology, 49, 65-85. doi:10.1146/annurev.psych.49.1.65

Powell, K. A. (2011). Framing Islam: An analysis of US media coverage of terrorism since 9/11. Communication Studies, 62(1), 90-112. doi:10.1080/10510974.2011.533599

Reeves, B., Yeykelis, L., \& Cummings, J. J. (2016). The use of media in media psychology. Media Psychology, 19(1), 49-71. doi:10.1080/15213269.2015.1030083

Riedel, B. (2011, December 9). The grave new world: Terrorism in the 21st century. Retrieved from https://www.brookings.edu/articles/the-grave-new-world-terrorism-in-the-21st-century/

Riffkin, R. (2015, December 14). Americans name terrorism as No. 1 U.S. problem. Retrieved from http://www.gallup.com/poll/187655/americans-name-terrorism-no-problem.aspx

Rothgerber, H. (1997). External intergroup threat as an antecendent to perceptions of in-group and out-group homogeneity. Journal of Personality and Social Psychology, 73(6), 1206-1212. doi:10.1037/0022-3514.73.6.1191 
Ryan, C. S., Judd, C. M., \& Park, B. (1996). Effects of racial stereotypes on judgments of individuals: The moderating role of perceived group variability. Journal of Experimental Social Psychology, 32 (1), 71-103. doi:10.1006/jesp.1996.0004

Satti, M. (2015). Framing the IS on Al Jazeera English and the BBC websites. Journal of Arab \& Muslim Media Research, 8(1), 37-53. doi:10.1386/jammr.8.1.37_1

Schmuck, D., \& Matthes, J. (2015). How anti-immigrant right-wing populist advertisements affect young voters: Symbolic threats, economic threats, and the moderating role of education. Journal of Ethnic and Migration Studies, 4l(10), 1577-1599. doi:10.1080/1369183X.2014.981513

Schmuck, D., \& Matthes, J. (2017). Effects of economic and symbolic threat appeals in right-wing populist advertising on anti-immigrant attitudes: The impact of textual and visual appeals. Political Communication. Advance online publication. doi:10.1080/10584609.2017.1316807

Sides, J., \& Gross, K. (2013). Stereotypes of Muslims and support for the war on terror. The Journal of Politics, 75(3), 583-598. doi:10.1017/S0022381613000388

Slone, M. (2000). Responses to media coverage of terror. Journal of Conflict Resolution, 44(4), 508522. doi:10.1177/0022002700044004005

Stanford Mapping Militant Organizations Project. (2016, April 4). Mapping militant organizations. The Islamic State. Retrieved from http://web.stanford.edu/group/mappingmilitants/cgi-bin/groups/ view/1

Stephan, W. G., Renfro, C. L., Esses, V. M., Stephan, C. W., \& Martin, T. (2005). The effects of feeling threatened on attitudes toward immigrants. International Journal of Intercultural Relations, 29(1), 1-19. doi:10.1016/j.ijintrel.2005.04.011

Stephan, W. G., \& Stephan, C. W. (2000). An integrated threat theory of prejudice. In S. Oskamp (Ed.), Reducing prejudice and discrimination (pp. 23-45). Mahwah, NJ: Erlbaum.

Stephan, W. G., Ybarra, O., \& Morrison, K. R. (2009). Intergroup threat theory. In T. D. Nelson (Ed.), Handbook of prejudice, stereotyping, and discrimination (pp. 43-59). New York, NY: Psychology Press.

Strabac, Z., \& Listhaug, O. (2008). Anti-Muslim prejudice in Europe: A multilevel analysis of survey data from 30 countries. Social Science Research, 37(1), 268-286. doi:10.1016/j.ssresearch.2007.02.004

Tajfel, H., \& Turner, J. C. (1986). The social identity theory of intergroup behavior. In S. Worchel \& L. W. Austin (Eds.), Psychology of intergroup relations (pp. 276-293). Chicago, IL: NelsonHall.

Teo, P. (2000). Racism in the news: A critical discourse analysis of news reporting in two Australian newspapers. Discourse \& Society, 11(1), 7-49. doi:10.1177/0957926500011001002

U.S. Department of State. (2016). Foreign terrorist organizations. Retrieved from http://www.state. gov/j/ct/rls/other/des/123085.htm

Voci, A., \& Hewstone, M. (2003). Intergroup contact and prejudice toward immigrants in Italy: The mediational role of anxiety and the moderational role of group salience. Group Processes \& Intergroup Relations, 6(1), 37-54. doi:10.1177/1368430203006001011

Woods, J. (2011). Framing terror: An experimental framing effects study of the perceived threat of terrorism. Critical Studies on Terrorism, 4(2), 199-217. doi:10.1080/ 17539153.2011 .586205

Zhang, X., \& Hellmueller, L. (2016). Transnational media coverage of the ISIS threat: A global perspective? International Journal of Communication, 10, 766-785. 


\section{APPENDIX}

\section{Excerpt of News Article 1}

\section{News Outlet: Der Standard (derstandard.at)}

Headline: Extremism in Austria. Member of the IS planned terrorist attack in Vienna. Statement: Timothy Welkner, jihadism expert of the University of Oxford (fictitious) Undifferentiated version: "The Internet facilitates the networking and radicalization process of Muslims. Recently, young men and women out of the center of the Muslim society increasingly deal with the Islam religion. They visit the services at the Mosque, read Koran extracts or watch propaganda videos. In doing so, they sympathize with violent extremists or become more extremist themselves within a very short period of time."

Differentiated version: "The Internet facilitates the networking and radicalization of these people. They become extremists. At this point it is important to stress, however, that this propensity to violence has nothing to do with the Islam religion and the high number of well-integrated Muslims in our society. It's important to clearly distinguish between the IS and peaceful Muslims. These violent acts are incompatible with the Islam religion."

\section{Excerpt of News Article 2}

\section{News Outlet: Kurier (kurier.at)}

Headline: Europol warns of major terrorist attacks by the IS: High risk for Vienna Statement: Rob Wainwright, Europol director

Undifferentiated version: "Self-radicalizations of Muslims often occur in the center of Muslim communities or mosques. In particular, Salafist tendencies provide the ground for these radicalizations. It's important that we locate Muslim extremists as soon as possible. This is a core task of the Europol anti-terror center".

Differentiated version: "In the war against terror by the IS Muslim organizations and communities provided crucial information. They are on our side. Together we pursue the same goal within the war against the terror by the IS. Without the help of our Muslim partners, we would not have been able to prevent several attacks by IS terrorists."

\section{Excerpt of News Article 3}

News Outlet: Die Presse (diepresse.com)

Headline: "Islamic State": Smuggled Austrian passports in Vienna

Statement: Hamid Hamdan, Islam expert

Undifferentiated version: "This is a serious problem. But an even bigger problem is the radicalization of young men who are born here. They already have Austrian passports. We have to take actions against these fundamentalists and 
extremist organizations, because Islam and its organizations naturally have a problem with violence."

Differentiated version: "This is a serious problem. But it's also a big problem that this could lead to general suspicion toward peaceful Muslims who have lived and worked here for a long time and have nothing to do with this kind of extremism and terror. We have to avoid this by all means. Christians, Jews and Muslims have to stand together and oppose these fundamentalists."

The full versions of all articles are not printed here due to space constraints but are available from the authors upon request. Please note that the parts not shown here were equal in all conditions. 